\title{
The effect of moderate-intensity physical load and concentration of PTH hormone on raising bone densityin women
}

\section{Dr.Heba Fathy Heikal}

Faculty of physical Education for Girls, University of Alexandria.

\section{Dr.Dina Farouk Atef}

Faculty of physical Education for Girls,

University of Alexandria.

\section{Research introduction:}

The risk of physical injury has increased significantly, not only among athletes, but also among ordinary individuals. That risk has become common among women especially in advanced age. Technological development has led to a lack of movement and consequent health problems. This prompted people to practice sports in order to maintain health and prevent injuries. (9:47)

Many countries are interested in conducting research and studies in analyzing the relationship between sport activity and human health. Abu Al-Ela (2003) emphasized that regular physical activity reduces health risks, increases the individual's ability to face challenges of life, and reduces mobility diseases such as neck pain, low back pain, arthritis, osteoporosis, and feeling tired quickly. Pain makesindividual loses the ability to exert effort and continue life. (9: 629)

Samira Orabi and Manar Salama (2010) also emphasize that practice of sporthas a great effect on maintaining woman fitness and physical health, especially withthe technological progress and modern life that led to lack of movement. The best wayto prevent injury is through full awareness of the importance of physical activity. (20) Physical activity raises physical and physiological fitness of the 


\section{International Journal of Sports Science and Arts}

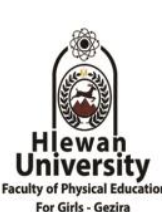

individual so that hisvital organs are capable of performing their required functions well. (30:331) Physical activity is also considered the main tool of making positive physiologicaleffects to the body, taking into account the gradient increasing of the load because theefficiency of the body systems works at its maximum for a certain period of time untilthe desired effect occurs. (19: 28-29)

Many specialists believe that directed and regulated physical effort by controlling size, intensity and load prevents women injuries and that there are levels of physical loads. (30:237)

The appropriate load must be taken into account for each individual, as indicated by Abu Al-Ela Abdel-Fattah and Mohamad Sobhi (2003) that increasing the training load more than the individual's ability leads to a weakening of the immune system that leads to individual injuries. (12: 4)

Bones are the main reservoir for calcium salts. Bones are living tissue that has a collagen protein origin impregnated with calcium and phosphates, and these two elements are always changing, meaning that the bone is in a state of remodeling between resorption and deposition (26:238)

The lack of movement and lack of physical exercise are the main reasons for women that cause osteoporosis, the lack of mineral salts in the bones, which leads to the risk of fractures, especially in women after menopause. In osteoporosis, the bone is less strong than normal and there is a great decrease in bone mass and it is susceptible to fracture. Women after menopause lose bone at accelerated rates, therefore bone density must be measured continuously. Physical exercise is one of the means to help prevent and even treat osteoporosis. (2:110) 


\section{International Journal of Sports Science and Arts}

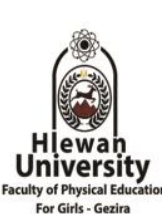

Physical activities and exercise have a noticeable effect on the skeleton, as continuous movement is necessary to get healthy and strong bones. Physical activities help in increasing the size of the bones due to the pressure exerted on the bone during the practice of sports activities. As for the lack of movement, it leads to a defect in the bones or a defect in its function. Among the benefits of sports activities for the bones is that they help to stimulate blood circulation in the bone tissue to supply this tissue with the vital elements that it needs in its construction, and they also help to activate the bone marrow that produces red blood cells. Therefore, physical activities enhance the bone marrow to produce more red blood cells. (24:24) $(15: 30)$

Mohamed Ibrahim and Sabah Farooz (2010) add that during regular activity, the muscle tension exerted on the bones maintains the integrity and health of bone tissue. (28:20)

The hormonal system, along with the nervous system, regulates the rates of chemical activity of the body's cells and bone tissue.

Khaled Nammoura (2017) states that the Parathyroidhormone is a regulator of calcium exchange and its function to maintain calcium concentration in the extracellular fluid. (17:22)

Formica (2011) noted that this hormone maintains the level of calcium in the blood, as it works to replenish calcium from the bones in a feedback regulation process in which the calcium released from the bones controls the release of the hormone fromthese glands and decrease it (3)

Disorders of the secretion of Parathyroidhormone from the parathyroid glands (increase and decrease) lead to a decrease in the 


\section{International Journal of Sports Science and Arts}

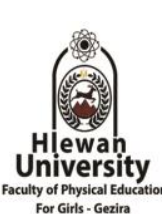

amount of calcium and phosphorous in the body, and consequently the bones are affected and become more susceptible to fracture. The measurement of Parathyroidhormone concentrations in the blood isdone by "radioimmunoassay method".

$(29: 976)$

Through reviewing many researches and scientific studies, the two researchers noted that there are studies on the relationship between exercise and the concentration of the PTH hormone, such as the study of Hodsman RM (2016), Anissa bouassida (2014) aiming to identify the effect of sport on the secretion of the Parathyroid hormone. Some studies on the relationship of exercise on increased bonemineral density, such as the study of Nabil Jaafar, Al Ameer Mohamed (2009) which aimed to identify the effect of an exercise program with nutritional supplement to reduce osteoporosis in women aged (45-55) years, and the study of Amjad Mohamed Hussein Mohamed Lama (2007), which aimed to identify The effect of weight training on bone mineral density, muscle strength and the level of skill performance of football juniors, and the study of Walid Mostafa Darwish, Azza Ibrahim Khalil (2007) which aimed to identifying the effect of shock training exercises to develop muscle capacity on bone mineral density, speed, and accuracy of passing among basketball juniors. However, up to the knowledge of the two researchers, there is a shortage in research linking the relationship between exercise with the concentrationof the PTH hormone and the increasing bone mineral density. Hence the idea of the current research, which is "the effect of moderate-intensity physical load and the concentration of the PTH hormone on raising bone density in women" (1) (5) (38) (15) (40) 


\section{International Journal of Sports Science and Arts}

\section{Research Objectives:}

1 .To identify the effect of moderate intensity physical load on the concentration ofthe PTH hormone in the research sample of women.

2 .To identify the effect of moderate intensity physical load on the bone mineraldensity in the research sample of women

3 .Identify the effect of a moderate-intensity physical program on the musclestrength and joint flexibility in the research sample of women.

\section{Research hypotheses:}

1 .There are statistically significant differences between the pre and post measurements in the PTH hormone concentration in the research sample ofwomen.

2 .There are statistically significant differences between the pre and post measurements in the bone mineral density in the research sample of women.

3 .There are statistically significant differences between the pre and post measurements in the muscle strength and joint flexibility in the research sampleof women.

4 .There is a significant positive effect of applying moderate intensity physical loadon the concentration of the PTH hormone in the research sample of women.

5 .There is a significant positive effect of applying moderate intensity physical loadon the bone mineral density in the research sample of women.

6. There is a significant positive effect of applying the moderate intensity physical program on the muscular strength and joint flexibility in the research sample of women.

\section{Research Vocabulary:}




\section{International Journal of Sports Science and Arts}

\section{Parathyroid hormone (PTH):}

It is the hormone produced by the parathyroid gland that controls the concentration of calcium ions in the extracellular fluid by controlling the absorption of calcium from the intestine, the excretion of calcium by the kidneys, and the releaseof calcium from the bones.

(31: 970)

\section{Research procedures:}

\section{Research Methodology:}

The two researchers used the experimental method due to its suitability to the nature of the research, by using a single experimental group, and a pre and post measurement was performed for all the variables of the research.

\section{Research Scope:}

\section{The human scope:}

Women from 40 to 55 years old.

\section{Place scope:}

The research was applied in the Physical Fitness Unit of the faculty of PhysicalEducation for Girls.

\section{Time scope:}

Physical load (exercise program) was applied in a period of 3 months (3 units perweek) from 15/9/2020 to 15/12/2020.

\section{The research sample:}

The research sample was deliberately selected and included women whose agesrange from 40 to 55 years. The total research sample was (20 women)

\section{Sample inclusion conditions:}

1- The research sampleagree to participate in the research. 


\section{International Journal of Sports Science and Arts}

2- Age is not less than 40 years.

3- The research sampleare not subjected to any other sports programs.4- The research sample suffer from bone problems.

5- The research samplevolunteer to conduct a research experiment.

6- The research sample are not practicing any sporting activity

7- The research sample are committed to the sports program during the researchperiod

\section{Sample homogeneity:}

\section{Table (1)}

Statistical description of the research sample data in the primary variablesbefore the experiment

$$
\text { ( } n=20)
$$

\begin{tabular}{|c|c|c|c|}
\hline $\begin{array}{l}\text { Statistical ParametersPrimary } \\
\text { variables }\end{array}$ & $\begin{array}{c}\text { Arithmetic } \\
\text { mean }\end{array}$ & $\begin{array}{l}\text { standaro } \\
\text { deviation }\end{array}$ & $\begin{array}{l}\text { Skewness } \\
\text { coefficient }\end{array}$ \\
\hline Age (years) & 49.771 & 3.293 & -0.396 \\
\hline Height $(\mathrm{cm})$ & 162.368 & 5.090 & 0.870 \\
\hline Weight (Kg) & 81.00 & 6.455 & 0.496 \\
\hline $\begin{array}{l}\text { concentration level of PTH hormone inthe } \\
\text { blood }(\mathrm{Pg} / \mathrm{ml})\end{array}$ & 26.494 & 3.631 & 0.403 \\
\hline
\end{tabular}

Table (1) shows the statistical description of the research sample data in the primary variables before the experiment (age, height, weight, blood analysis before load). The Skewness coefficient ranged between $(-0.396$ to 0.870$)$, and these values are close to zero, which confirms the homogeneity of the data and that it isnot dispersed.

\section{Tools and devices}

- Restameter device to measure height to the nearest $(\mathrm{cm})$, medical scale tomeasure weight to the nearest $(\mathrm{kg})$.

- Plastic syringes for single use only, medical cotton and medical patches. 


\section{International Journal of Sports Science and Arts}

- Special tubes for collecting blood samples, sealed to reserve blood for analysis.

- A form for the approval of the research sample to draw blood samples

- Muscular strength and joint flexibility tests

- DEXA device to measure bone mineral density

- The genometer device to measure joint flexibility.

- A centimeter tape, adhesive tape, Swedish seat.

\section{Laboratory Measurements:}

- PTH hormone analysis

- X-ray measurement of mineral bone density.

\section{Anthropometric measurements:}

- Measure of height.

- Measure of weight.

\section{Physical measurements:}

- Measurement of muscle strength: arms, abdomen, back, and legs.

- Flexibility measurement: shoulders, spine, thighs.

\section{Research Executive Steps:}

1-Exploratory studies: (8) women were identified, and tests (strength and flexibility) were applied on them as a first Exploratory study, and (4) women werechosen to apply the second exploratory study on them, where the sports program was tried on them.

2-The sports program: (20) women were chosen to represent the research sample, for whom moderate intensity physical load was applied, ranging between(50: 60\% pulse/ minute) of maximum tolerance.

First: Warm-up: (5 minutes): It aims at:

- Preparing the body for the upcoming activity. 


\section{International Journal of Sports Science and Arts}

- The transition from a state of rest to a state of activity through the warm-upphase.

- Protect the individual from the occurrence of injuries.

- Preparing the respiratory system to work.

- Increase the heart rate for training.

- Activate muscles gradually.

- It increases the capacity of the circulatory system.

Second: Physical preparation: (30 minutes) (Muscular strength jointflexibility): It aims at:

-Strengthening working muscles and ligaments in every exercise.

-Increase the range of working joints in each exercise.

-Increase muscle elasticity and working ligaments in every exercise.

- Activate the involuntary physiological functions necessary for the bodyactivity.

- Place the central and peripheral nervous system in the best condition toperform effectively.

Third: Cool down (5 minutes): It aims at:

- Return of the body to its normal state before training.

- Elimination of metabolic waste products that resulted during exercise

\section{3- Pre measurements:}

The following measurements were taken:

- Measuring the bone mineral density of the research sample in the Department of Radiology and Medical Imaging at Mabaret Al-Asafra Hospital in Alexandria from (1/9/2020 to 4/9/2020)

- Measuring the concentration of the PTH hormone at Mabaret AlAsafra laboratoryfrom (6/9/2020: 7/9/2020)

- Taking anthropometric measurements (height and weight) and physical measurements (joint flexibility and muscle strength) in the 


\section{International Journal of Sports Science and Arts}

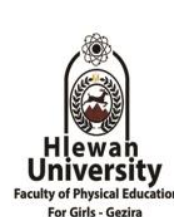

fitness hall of the Faculty of Physical Education for Girls, Alexandria University from (9/9/2020 to11/9/2020)

\section{4- Application of the sports program:}

The sports program was implemented from (15/9/2020 to 15/12/2020).

\section{5- Post measurements:}

The following measurements were taken:

- Measuring the bone mineral density and analyzing the PTH hormone for the research sample in the Electromagnetic waves department at Mabaret Al-Asafra Hospital in Alexandria during the period (16/12/2020 to $17 / 12 / 2020)$

- Taking anthropometric measurements (height and weight), physical measurements (joint flexibility and muscle strength) in the fitness hall of the Faculty of Physical Education for Girls, Alexandria University on (18/12/2020 to 20/12/2020).

\section{Statistical Analysis:}

1- Arithmatic Mean

2-Standard Deviation

3- T test

4- Improvement Percentage

5- Effect coefficient.

\section{Results and discussion:}

The first hypothesis: There are statistically significant differences between the pre and post measurements in the PTH hormone concentration in the research sample of women., and the fourth hypothesis: There is a significant positive effect of applying moderate intensity physical load on the concentration of the PTH 


\section{International Journal of Sports Science and Arts}

hormone in the research sample of women.

\section{Table (2)}

Differences between pre-load measurement and post-load measurement in theconcentration level of PTH hormone in the blood sample under investigation (moderate load) $(n=20)$

\begin{tabular}{|c|c|c|c|c|c|c|c|c|c|}
\hline \multirow[t]{2}{*}{$\begin{array}{l}\text { Statistical } \\
\text { Parameter }\end{array}$} & \multicolumn{2}{|c|}{ Pre load } & \multicolumn{2}{|c|}{ Post load } & \multicolumn{2}{|c|}{$\begin{array}{c}\text { Difference } \\
\text { between } \\
\text { means }\end{array}$} & \multirow[t]{2}{*}{ t value } & \multirow[t]{2}{*}{$\begin{array}{l}\text { Effect } \\
\text { value }\end{array}$} & \multirow[t]{2}{*}{$\begin{array}{c}\text { Effect } \\
\text { size }\end{array}$} \\
\hline & mean & $\pm S D$ & mean & $\pm S D$ & mean & $\pm \mathrm{SD}$ & & & \\
\hline $\begin{array}{l}\text { concentration level } \\
\text { of PTH hormone in } \\
\text { the blood }(\mathrm{Pg} / \mathrm{ml})\end{array}$ & 26.680 & \begin{tabular}{|l|l|}
3.297 \\
\end{tabular} & 49.210 & 4.233 & 22.530 & \begin{tabular}{|l|l|}
3.087 \\
\end{tabular} & $23.079^{*}$ & 7.298 & high \\
\hline
\end{tabular}

* Significance at 0.05 level $=2.093$

effect size value (weak 0.2, average 0.5 , large / high 0.8 and more)

It is evident from Table (2) and Figure (1) the presence of significant differences inthe concentration of the PTH hormone at the level of 0.005 , as the value of $t$ reached 23.079 , and this value is greater than its tabular value. The effect value was (7.298), which are high effect size.

60

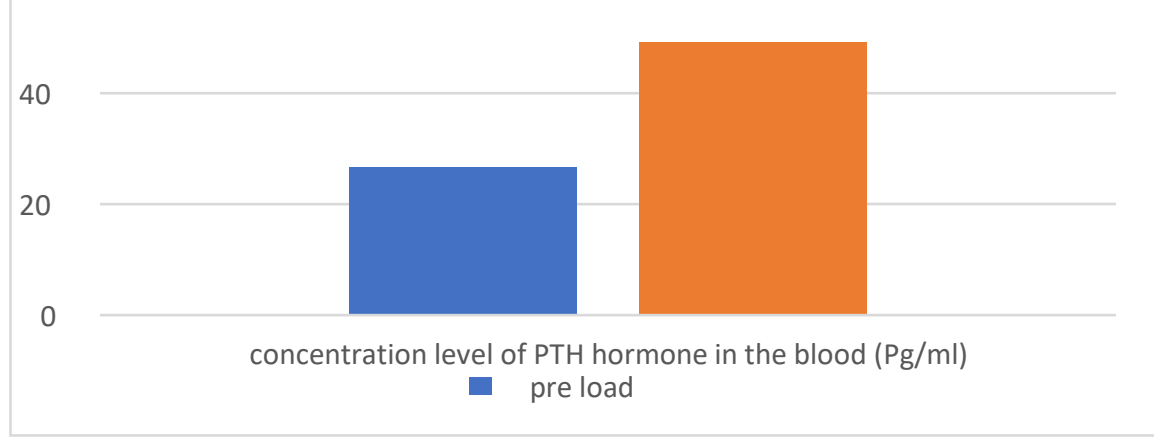

Figure (1)

Differences between pre and post-load measurement in the concentration ofthe PTH hormone in blood 


\section{International Journal of Sports Science and Arts}

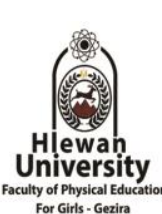

The researchers attribute these results to that moderate physical load led to thesecretion of the hormone at an optimal rate>

This result is confirmed by Ahmad Nasr Al-Din and Abu Al-Ela Abd El Fattah (2003) that moderate-intensity physical loads have a positive effect on the concentration of hormones and its secretion in the blood. (13: 148) (11:163)

- Abu Al-Ela Abd El Fattah (2003) also adds that physical load has an effect on hormonal functions, as scientific results confirm the vital role of sport with regard to positive health effects on controlling the hormonal system, and that the Parathyroidhormone secreted by the parathyroid gland increases its secretion duringphysical load.

Mohamed Othman (2010) and Osama Riyad (2009) agree that the practice of sport activity through physical effort rated in load, size and intensity represents a basic mean of influencing the functional level of vital systems and endocrine glands. (35:237)(14:24)

- The results of the current study are consistent with the results of the study of bothFathi Abd Al-Rahman (2012) and Tariq Salah ElDin (2011), as their results showedthat there is an effect of practicing sport activities of different intensities on increasing the secretion of hormones in the blood. (27) (23)

This is confirmed by Abu Al-Ela Abd El Fattah (2003) that moderate-intensityphysical exercise affects the increase in hormone secretion in the blood, and high- intensity sports activities have a harmful effect on the body due to the massive increase in hormone secretion. (11: 439)

- Mohamed Adel Rushdi (2009) explains that simple exercise does not affect the rates of secretion of the glands, and that 


\section{International Journal of Sports Science and Arts}

moderate exercise protects the individual from injuries, while violent and strenuous exercise affects the hormonal system andthe glands.

Tammy Thachuk (2014) noted that moderate-intensity athletic activities play a large role in the secretion of hormones and an increase in the level of mineral salts, and that high-intensity exercises have negative effects on the secretion of hormones in the blood. (7)

Hence, the first hypothesis, which states that there are statistically significant differences between the pre and post measurements in the PTH hormone concentration in the research sample of women., and the fourth hypothesis which states that there is a significant positive effect of applying moderate

intensity physical load on the concentration of the PTH hormone in the researchsample of women, are achieved

The second hypothesis:There are statistically significant differences between the pre and post measurements in the bone mineral density in the research sample of women and the fifth hypothesis: There is a significant positive effectof applying moderate intensity physical load on the bone mineral density in the research sample of women. 


\section{International Journal of Sports Science and Arts}

\section{Table (3)}

Differences between pre and post measurements in physiologicalmeasurements (bone mineral density) (YA T score $)(n=20)$

\begin{tabular}{|c|c|c|c|c|c|c|c|c|c|}
\hline \multirow{2}{*}{ arameterTests } & \multicolumn{2}{|c|}{ Pre load } & \multicolumn{2}{|c|}{ Post load } & \multicolumn{2}{|c|}{$\begin{array}{c}\text { Difference } \\
\text { between means }\end{array}$} & \multirow[t]{2}{*}{$\begin{array}{c}\mathrm{t} \\
\text { value }\end{array}$} & \multirow[t]{2}{*}{$\begin{array}{l}\text { Effect } \\
\text { value }\end{array}$} & \multirow[t]{2}{*}{ Effectsize } \\
\hline & \begin{tabular}{|l|} 
mean \\
\end{tabular} & $\pm \mathrm{SD}$ & mean & $\pm \mathrm{SD}$ & mean & $\pm \mathrm{SD}$ & & & \\
\hline Neck & 527 & 0.430 & 7 & 0.428 & 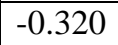 & 0.063 & $16.045^{*}$ & -5.079 & bi \\
\hline Wards' triangle & 1.696 & 0.490 & -1.337 & 0.455 & \begin{tabular}{|l|}
-0.359 \\
\end{tabular} & 0.099 & 11.436* & -3.626 & $\mathrm{~h}$ \\
\hline Troc & $\mid-0.682$ & 0.102 & -0.448 & 0.089 & -0.234 & 0.071 & $10.391 *$ & -3.296 & high \\
\hline Total & 1.224 & 0.281 & -0.906 & 0.230 & \begin{tabular}{|l|}
-0.318 \\
\end{tabular} & 0.142 & $7.084 *$ & -2.239 & high \\
\hline
\end{tabular}

* Significance at 0.05 level $=2.093$

effect size value (weak 0.2 , average 0.5 , large / high 0.8 and more)

It is evident from Table (3) and Figure No. (2) of the differences between the pre- and the post-measurement in physiological measurements (bone mineral density) and the presence of significant differences between the two measurements at a level of 0.05 in favor of the post-measurement in all measurements, where the calculated value of $t$ ranged between (7.084 to 16.045) and these values are greater than the tabular value of $t$. The effect value ranged between (2.39 to 5.079), which are high effect size.

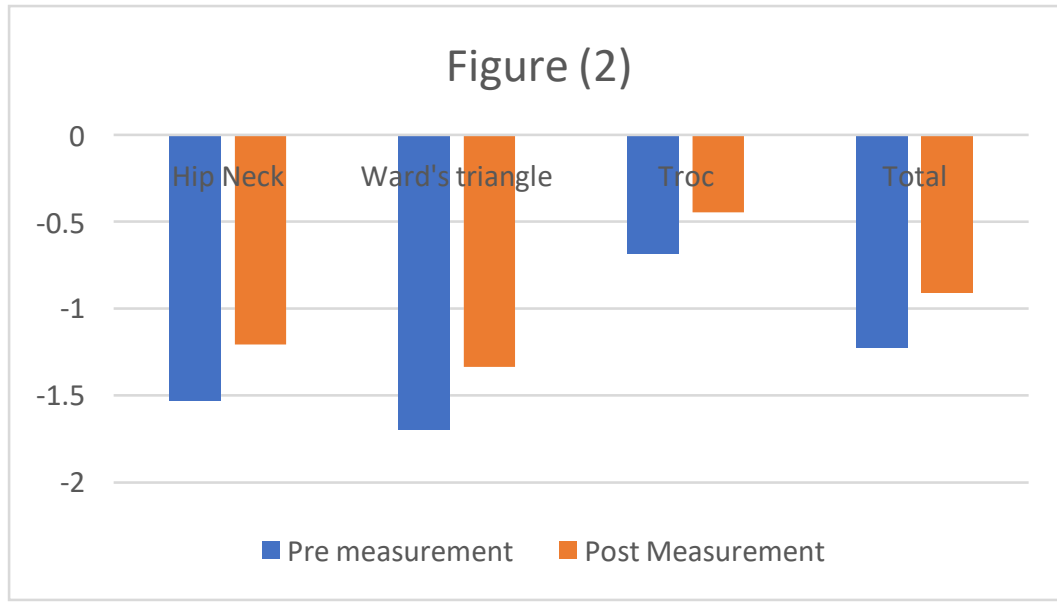

Volume (018), Issue (1) February 2021

web: eijssa.journals.ekb.eg Email: ijssa@pef.helwan.edu.eg 


\section{International Journal of Sports Science and Arts}

Figure (2)

\section{average pre- and post- physiological measurements (bone mineral density)}

The two researchers attribute these results to that the moderate-intensity exercise program helped increase bone mineral density.

This is also in agreement with the results of Reem Abdel Sattar study (2014) that sports programs are effective in improving the percentage of osteoporosis and preventing the increase in the rate of fragility among women. (20)

This is in consistent with the study of Hala Yahya Al-Sayed (2015), who concludedthat there are statistically significant differences between the pre and post measurements in bone density in favor of the post measurement. (39)

The shock exercises, as the jump exercises, work to develop the muscle strength andits role extends to increasing bone mineral density of the body. Abu Al-Ela (2003) states that physical exercise in general is considered one of the means to increase bone density. (11)

This was confirmed by the results of Nabil Jaafar study (2009) that the practice of sporting activity and physical exercises improves the level of bone density of the spine and thigh for women after the age of (55) years. (38)

Mohamed Al-Hamahami (2000) states that exercises on the ground have a greater effect on bones, as shock exercises with the ground increase muscle strength and itsrole extends to the bone mineral density. (36)

This is in agreement with the results of Walid Mostafa and Azza 


\section{International Journal of Sports Science and Arts}

Khalil (2017)that shock exercises have a positive effect on the muscular capacity of the legs and on the mineral density of the spine and pelvis. (40)

Talha Hosam Al-Din (2012) also emphasizes that stresses on the bone works to deposit salts properly, and therefore most of those who practice sports are heavier, and this is what the results of the current study brought about in that it increased bone density.

O'brien, M (2011) added that the practice of continuous sports activities during the different stages of life leads to the prevention of bone loss in old age dueto the increased deposition of bone calcium resulting from the regular and continuous increase in the deposition process more than the resorption process, which helps to increase bone mass and always preserve it (5: 62)

Abu Al-Ela Abd El-Fattah (2003) also indicated that as a result of sports training, morphological functional changes occur in the locomotor system (muscles - bones -tendons - ligaments). Muscles and bones increase in size, as it has been proven to increase in the transverse position of the bones and the thickness of their shell, whichleads to improvement of the mechanical properties of the bones. $(165: 11)$

JOHN (2010) added that there is a direct relationship, the more a person exercises physical activity, the stronger the bones and increased hardness and density increased. (4)

Hence, the results of the second hypothesis, which states that there are statistically significant differences between the pre and post measurements in the bone mineral density in the research sample of women and the fifth hypothesis which 
states that there is a significant positive effect of applying moderate intensity physical load on the bone mineral density in the research sample of women, are achieved.

The third hypothesis: There are statistically significant differences between the pre and post measurements in the muscle strength and joint flexibility in the research sample of women and the sixth hypothesis: There is a significant positive effect of applying the moderate intensity physical program on the muscular strength and joint flexibility in the research sample of women.

\section{Table (4)}

The differences between pre-measurement and postmeasurement in physicaltests for the two components of muscular strength, characterized by velocity and muscular endurance $(n=20)$

\begin{tabular}{|c|c|c|c|c|c|c|c|c|c|c|}
\hline \multirow{2}{*}{\multicolumn{2}{|c|}{ Physica Test }} & \multicolumn{2}{|c|}{ Pre load } & \multicolumn{2}{|c|}{ Post load } & \multicolumn{2}{|c|}{\begin{tabular}{l|} 
Difference \\
between \\
means
\end{tabular}} & \multirow[t]{2}{*}{ t value } & \multirow{2}{*}{\multicolumn{2}{|c|}{$\begin{array}{l}\text { Effect Effectsize } \\
\text { value }\end{array}$}} \\
\hline & & mean & $\pm S D$ & mean & $\pm S D$ & mean & $\pm S D$ & & & \\
\hline \multirow{3}{*}{$\begin{array}{l}\text { strength, } \\
\text { characteri } \\
\text { zed by } \\
\text { velocity }\end{array}$} & $\begin{array}{l}\text { number of Bent- } \\
\text { Knee Situp in } 10 \\
\text { seconds }\end{array}$ & 2.400 & 0.843 & 4.200 & 0.632 & 1.800 & \begin{tabular}{|l|}
1.033 \\
\end{tabular} & $5.511^{*}$ & 1.742 & high \\
\hline & $\begin{array}{l}\text { number of torso is } \\
\text { liftedup from prone } \\
\text { in } 10 \text { seconds }\end{array}$ & 2.300 & 0.675 & 4.200 & 0.632 & 1.900 & 0.568 & $10.585^{\star}$ & 3.345 & high \\
\hline & Wide jump (cm) & 44.612 & 5.444 & 64.900 & 4.149 & 20.288 & 7.052 & $9.098^{*}$ & 2.877 & high \\
\hline \multirow[t]{2}{*}{$\begin{array}{l}\text { muscular } \\
\text { endurance }\end{array}$} & $\begin{array}{l}\text { time for raising the } \\
\text { legsinclined high and } \\
\text { steadiness from } \\
\text { lyingdown (sec.) }\end{array}$ & 9.800 & 1.619 & 14.200 & 1.619 & 4.400 & 2.011 & $6.919^{*}$ & 2.188 & high \\
\hline & $\begin{array}{l}\text { number of times to } \\
\text { bendthe arms from a } \\
\text { tilted prone modified for } \\
\text { girlsin } 30 \text { seconds }\end{array}$ & 10.100 & 2.132 & 15.900 & 1.197 & 5.800 & 2.300 & $7.975^{\star}$ & 2.522 & high \\
\hline
\end{tabular}

* Significance at 0.05 level $=2.093$

effect size value (weak 0.2, average 0.5 , large / high 0.8 and more) 


\section{International Journal of Sports Science and Arts}

It is evident from Table (4) and Figure No(3) of the differences between the pre-and post measurement in physical tests (strength characterized by velocity) that the presence of significant differences between the two measurements at a level of 0.05 in favor of the post-measurement in all tests. The calculated value of $t$ between (5.511 to 10.585), these values are greater than the tabular $t$ value, and the effect value ranged between (1.742 to 2.877), which are high effectsize

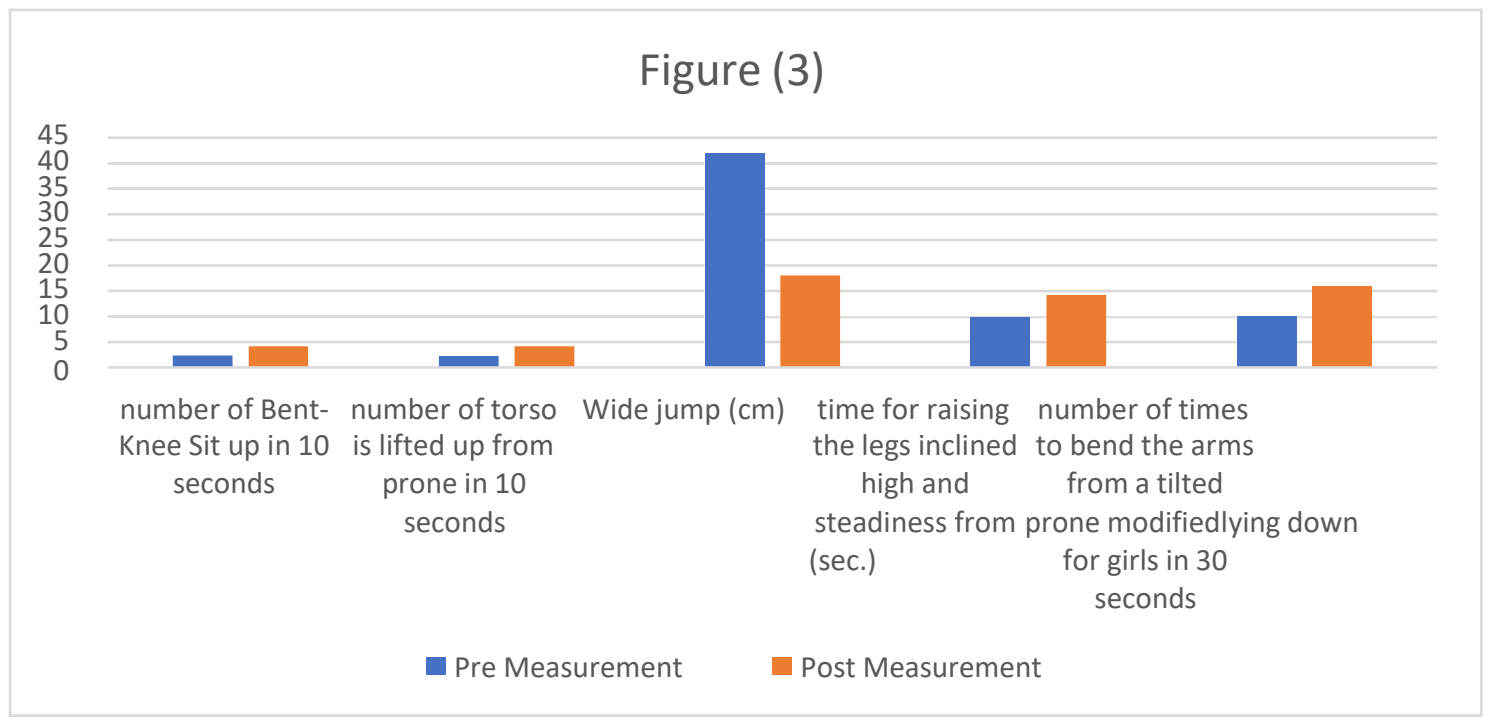

Figure (3)

Pre- and post-measurement in physical tests for the strength characterized byvelocity and muscular endurance 


\section{International Journal of Sports Science and Arts}

Table (5)

Differences between pre- and post-measurement in physical tests (flexibility) $(n=20)$

\begin{tabular}{|c|c|c|c|c|c|c|c|c|c|}
\hline \multirow{2}{*}{$\begin{array}{l}\text { Statistical Parameter } \\
\text { Physical } \\
\text { (flexibility) }\end{array}$} & \multicolumn{2}{|c|}{ Pre load } & \multicolumn{2}{|c|}{ Post load } & \multicolumn{2}{|c|}{$\begin{array}{c}\text { Difference } \\
\text { between means }\end{array}$} & \multirow[t]{2}{*}{ t value } & \multirow[t]{2}{*}{$\begin{array}{l}\text { Effect } \\
\text { value }\end{array}$} & \multirow[t]{2}{*}{ Effectsize } \\
\hline & mean & $\pm \mathrm{SD}$ & mean & $\pm \mathrm{SD}$ & mean & $\pm \mathrm{SD}$ & & & \\
\hline $\begin{array}{l}\text { Bend the trunk } \\
\text { backward from the } \\
\text { stand }(\mathrm{cm})\end{array}$ & 41.900 & 2.234 & 62.000 & 3.742 & 20.100 & 4.795 & $\begin{array}{c}13.257 \\
*\end{array}$ & 4.192 & high \\
\hline $\begin{array}{l}\text { Bend the trunk } \\
\text { forward from } \\
\text { downward from } \\
\text { standing on a } \\
\text { wood cube }(\mathrm{cm})\end{array}$ & -6.400 & 2.119 & -1.500 & 1.269 & -4.900 & 1.912 & $8.104 *$ & -2.563 & high \\
\hline $\begin{array}{l}\text { Flexibility of the } \\
\text { shoulders fullfrom } \\
\text { prone position }(\mathrm{cm})\end{array}$ & 11.100 & 1.853 & 15.200 & 1.476 & 4.100 & 2.378 & $5.452 *$ & 1.724 & high \\
\hline $\begin{array}{l}\text { Right thigh flexion } \\
\text { (degree) }\end{array}$ & 30.900 & 4.864 & 36.300 & 3.529 & 5.400 & 4.600 & $3.713 *$ & 1.174 & high \\
\hline $\begin{array}{l}\text { Right thigh } \\
\text { extension (degree) }\end{array}$ & 16.900 & 2.424 & 20.500 & 1.581 & 3.600 & 2.503 & $4.548 *$ & 1.438 & high \\
\hline $\begin{array}{l}\text { Right thigh } \\
\text { abduction (degree) }\end{array}$ & 24.600 & 5.016 & 33.200 & 1.814 & 8.600 & 5.379 & $5.056 *$ & 1.599 & high \\
\hline $\begin{array}{l}\text { Left thigh flexion } \\
\text { (degree) }\end{array}$ & 26.200 & 5.203 & 34.700 & 2.869 & 8.500 & 5.380 & $4.996 *$ & 1.580 & high \\
\hline $\begin{array}{l}\text { Left thigh extension } \\
\text { (degree) }\end{array}$ & 13.800 & 2.700 & 24.300 & 4.270 & 10.500 & 5.442 & $6.102 *$ & 1.929 & high \\
\hline $\begin{array}{l}\text { Left thigh abduction } \\
\text { (degree) }\end{array}$ & 21.500 & 3.629 & 32.800 & 2.044 & 11.300 & 4.762 & $7.504 *$ & 2.373 & high \\
\hline
\end{tabular}

* Significance at 0.05 level $=2.093$ effect size value (weak 0.2, average 0.5 , large / high 0.8 andmore)

It is evident from Table (5) and the Figure No. (4) of the differences between pre- and post-measurement in physical tests (flexibility). The presence of significant differences between the two measurements at a level of 0.05 in favor of the post- measurement in (all tests). The calculated value of $t$ rangedfrom 3.713 To 113.257 and these values are greater than the tabular $t$ value.The effect value ranged from 1.174 to 4.192 , which are high effectsize. 


\section{International Journal of Sports Science and Arts}

Figure (4)

Average pre- and post-measurement in physical tests of the flexibility component

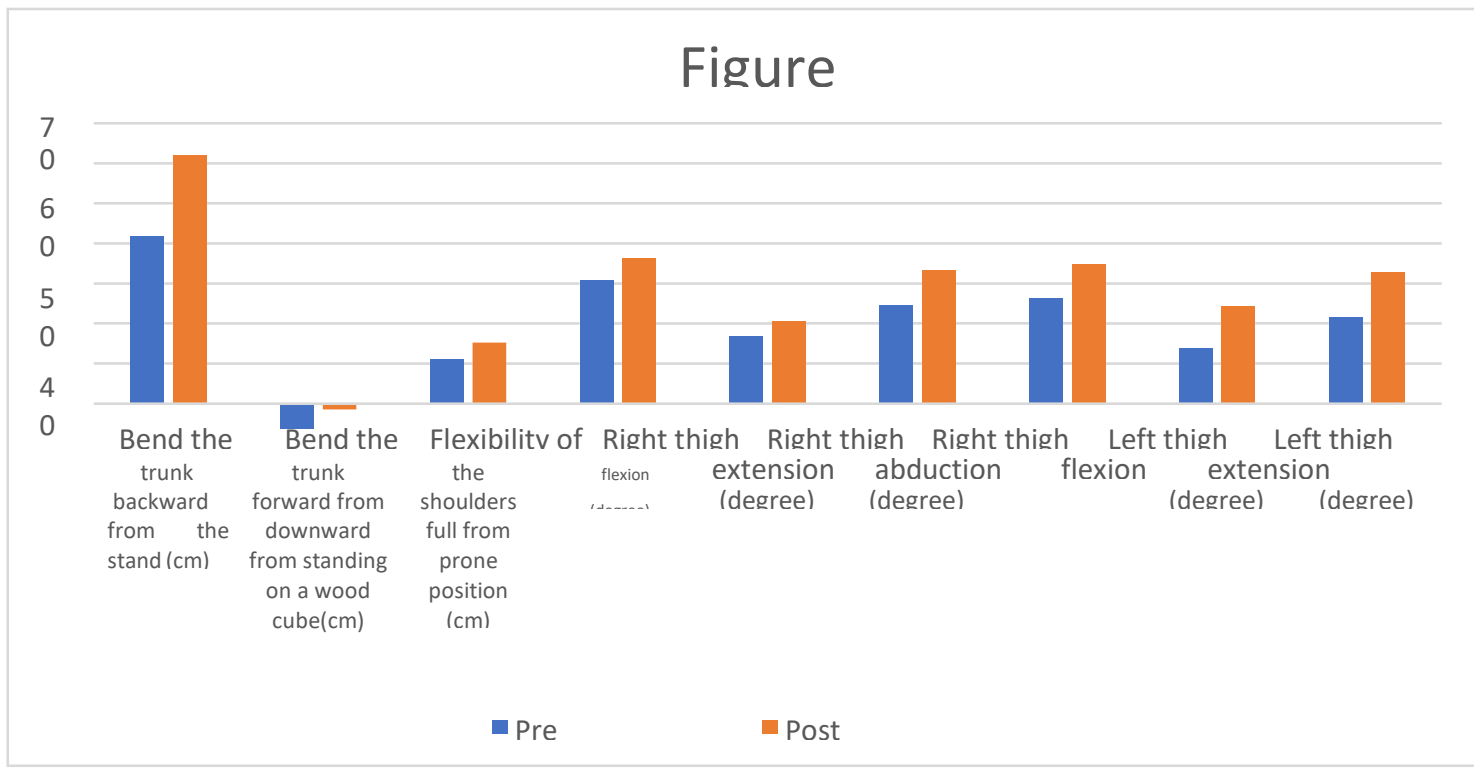

The two researchers attributed these results to the application of moderate- intensity physical load, which includes exercises for muscle strength and flexibility. Zakaria Hassan (2004) emphasized that muscle strength is one of the basic elements for practicing sporting activity. Owais Al-Jubaili (2000) and Abu Al-Ela Abd El Fattah (2003) believe that muscle strength training is one of the basic elements to gain physical fitness and works to improve the strength component that works to increase muscle mass and strengthen the connective tissue. (21:97) (25:24) (11:364)

Mohamed Hassan Allawi (2000), Mohamed Jaber Berriqa, and Ihab Fawzi (2005) agree that muscle strength is one of the most important physical traits on which an individual reaches the highest level of physical fitness, and this is what was achieved by the program that was applied on the research sample. (32:19)(33:14)

The Sand strom (2015) found that exercise increases muscle 


\section{International Journal of Sports Science and Arts}

strength. (6)

Abu El-Ela Abd El Fattah (2003) stresses the importance of sports training for the development of strength as it leads to an increase in muscle mass, strengthen connective tissues and the skeletal system, improving the structure of the individual's body, and developing other physical characteristics. (11:54)

This is in line with Reem Abd El Sattar's study (2014), which concluded the effect of a proposed program on increasing muscle strength. (20)

Eqbal Rasmy (2008) indicated that developing muscle strength is one of the most important factors that help prevent and reduce injuries. (16:31)

The study of Amjad Mohamed Husayn Mohamed (2007) noted that the use of a muscle strength program improves the muscular imbalance between the working muscle groups and the opposite muscles, and that the use of strength and flexibilityexercises reduces the incidence of injuries. (15)

Mohamed Berriqa and Ihab Ihab Fawzi (2005) indicated that standardized flexibility exercises work to preserve the full range of joint movement, which helpsreduce the incidence of injuries resulting from lack of joint flexibility. (33)

This is in consistent with the findings of Medhat Qasim Abd El Razek study (2010)regarding the effectiveness of flexibility and stretching exercises in preventing injuries and the necessity that flexibility and stretching exercises to be the most important parts of physical preparation in experimental programs. (37)

Abu El-Ela Abd El Fattah (2003) stresses the importance of linking flexibility and stretching exercises with strength exercises to 


\section{International Journal of Sports Science and Arts}

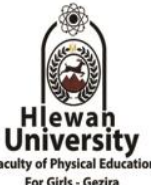

ensure work on thebalanced development of the musculoskeletal system $(11: 15)$

Thus, the results of the third hypothesis which states that There are statistically significant differences between the pre and post measurements in the muscle strength and joint flexibility in the research sample of women and the sixth hypothesis, which states that There is a significant positive effect of applying the moderate intensity physical program on the muscular strength and joint flexibility in the research sample of women, were achieved

\section{Conclusions:}

Based on the results of the study and in light of the objectives and hypothesis of the research and within the limits and characteristics of the research sample,

the method used, the tests and the measurements applied, the two researcherswere able to reach the following conclusions:

1. The moderate-intensity exercise program improved the PTH hormoneconcentration as shown by blood test results.

2. The medium-intensity exercise program improved the bone mineral density of the research sample as shown by the DEXA device.

3. The increase in the PTH hormone concentration in blood had a positiveeffect on increasing the bone mineral density.

4. The suggested moderate intensity exercise program and the increase in PTHhormone concentration led to an improvement in the bone mineral densityin the research sample as shown by the DEXA device.

5. The proposed moderate-intensity exercise program led to an 


\section{International Journal of Sports Science and Arts}

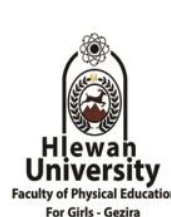

improvement in the muscle strength and joint flexibility in the research sample of women.

\section{Recommendations:}

In light of the research results and the conclusions reached, the two researchers havethe following recommendations that should be directed to all interested parties and all concerned parties specialized in the field of sports and in the fields of health sciences, especially for women and sports units:

1. Paying attention to moderate-intensity sports programs that increase bone densityand PTH hormone.

2. Paying attention to periodically checking bone mineral density, hormones of the thyroid glands and parathyroid glands to prevent injuries.

3. Paying attention to physical performance that maintains muscle strength and the range of motion of the women's joints in order to reduce the feeling of pain.

4. Paying attention to developing sports programs for women before and after menopause, which work to develop muscle strength and joint flexibility to gain physical fitness.

5. Establishing physical rehabilitation centers in the Faculties of Physical Education to apply the results of studies that serve the community.

6. Conducting similar studies on other samples of women, as they are more likely than men to lose bone density.

7. Conducting more similar studies on different age stages.

8. Application of this study to a larger sample. 